\title{
MENADŽMENT U KRIZNIM SITUACIJAMA - UZROCI I RAZMERE SVETSKE FINANSIJSKE KRIZE I PUTEVI IZLASKA
}

\author{
MANAGEMENT IN CRISIS - CAUSES AND SCALES OF \\ WORLD ECONOMIC CRISIS AND THE WAYS OF \\ OVERCOMING IT
}

\section{Tomislav Brzaković}

KBK Broker a.d., Beogradska 52, 11000 Beograd, Republika Srbija

\section{(C) MESTE NGO}

\section{Sažetak:}

Reč kriza spada među najčešće korišćene reči u poslednjih nekoliko godina. Finansijska kriza, primarno nastala u SAD krahom hipotekarnog kreditnog tržišta, brzo se proširila na ceo svet i pored finansijskog zahvatila i realan sektor. Uzroci krize se kreću od sistemskih karakteristika i institucionalnih svojstava privrede, do neadekvatnih ekonomskih politika i pohlepe pojedinih grupa, posebno finansijskih institucija $i$ kompanija. Danas u svetu finansijske transakcije daleko prevazilaze vrednost svetske trgovine, pojava poznata kao finansijalizacija, koja ima za posledicu transfer dohotka iz realnog u finansijski sektor. Mere koje se preduzimaju za izlazak iz krize su od istorijskog značaja, jer od njihove efikasnosti će zavisiti buduća konfiguracija svetskog finansijskog i ekonomskog sistema.

\section{Ključne reči:}

krizni menadžment, finansijska kriza, budžetski deficit, rizik

\begin{abstract}
:
The word crisis is among the most frequently used words in the last few years. The financial crisis, caused primarily in the U.S. by mortgage credit market collapse, quickly spread on the entire world and affected the financial as well as real sectors. Economic science looked differently on the crisis through the history. The causes of crisis ranged from system characteristics and institutional characteristics of the economy, to inadequate economic policies and the greed of certain groups, particularly financial institutions and companies. Today, the world's financial transactions far exceed the value of world trade, a phenomenon known as financialization, resulting in the transfer of real income in the financial sector. Measures taken to overcome the crisis are of historic significance because the future sustainable development and configuration of the global financial and economic system will depend on their effectiveness.
\end{abstract}

Adresa autora:

Keywwords:

Tomislav Brzaković

postal traffic, electronic services, new technology

麦=” tbrzakovic@kbkbroker.rs 


\section{Uvod}

Reč kriza spada u najčešće korišćene reči u poslednjih nekoliko godina. Koristi se višestruko, za opisivanje lične, odnosno porodične situacije (ostajanje bez posla, gubitak kuće ili stana usled nemogućnosti otplate stambenog hipotekatnog kredita, egzistencijalna kriza...), poslovne situacije (kriza likvidnosti, solventnosti...) ili krize celog društva (makroekonomska kriza, kriza otplate spoljnog duga, socijalna ili kulturološka kriza...). Nakon najveće ekonomske svih vremena, poznate kao Velika depresija, koja je trajala od 1929. do 1933. godine, krize se javljaju sve učestalije: velika dužnička kriza 1982., krah Wall Street-a 1987., Skandinavska kriza (Švedska, Norveška, Finska) 1991., Meksička Tequila kriza 1994., Velika azijska kriza (Japan, Tajland, Indonezija, Južna Koreja) 1997., Ruska kriza 1998., Brazilska kriza 1999., dotcom špekulativni balon 2000., Argentinska kriza 2001-2002. i najnovija globalna kriza iz 2008.godine. Većina kriza nakon Velike depresije su imale lokalni ili regionalni karakter, dok se najnovija kriza iz 2008.godine, primarno nastala u SAD, proširila i zahvatila gotovo ceo svet. Mnogi se sa pravom pitaju da li je moguće da je odlaskom sa životne scene većine svedoka razmera i težine Velike depresije svet zaboravio posledice i lako dozvolio da se situacija ponovi, uz iskazivanje zabrinutosti da je ekonomska nauka izgubila instinkt za opasnost, odnosno nije razvila mehanizme za blagovremeno prepoznavanja indikatora krize i mere za njeno efikasno suzbijanje. Pitanje da li je budućnost, a posebno krize, uopšte moguće predvideti je jedno od intrigrantnih pitanja današnjice. Kako priznaje nobelovac Robert Lukas, ekonomisti nemaju formulu kojom bi pouzdano predvideli trenutak kada će neki finansijski balon pući, a i da imaju to ništa ne bi promenilo, jer bi tu informaciju ljudi odmah ugradili u svoje odluke, pa bi se desilo samo to da kriza nastupi u trenutku kada je model ukazao.

Međutim, ako se pogledaju dva, možda najvažnija svetska indeksa akcija, Dow Jones Industrial Averages, koji iskazuje cene akcija 30 najboljih američkih kompanija (slika 1), i širi indeks S\&P 500 (Slika 2), koji obuvata akcije 500 najboljih svetskih kompanija, njihovim poređenjem sa najjednostavnijim tehničkim indikatorom pokretnim prosekom 200 (Moving averages - MA 200), koji ukazuje na promenu trenda koji se menja kada se vrednost indeksa počne kretati iznad ili ispod linije MA 200, može se videti da su oba indeksa ušla u negativan primaran trend sredinom 2008.godine. Negativni trend je trajao do avgusta 2009.godine, kada ponovo nastupa primarni rastući trend, sa kolebanjima sredinom 2010.godine, ali uz nastavak trenda. Od avgusta 2011. tržište akcija, mereno ovim indeksima, ponovo pada naredna dva meseca, da bi posle toga ušlo u blagi, ali kolebljiv rast.

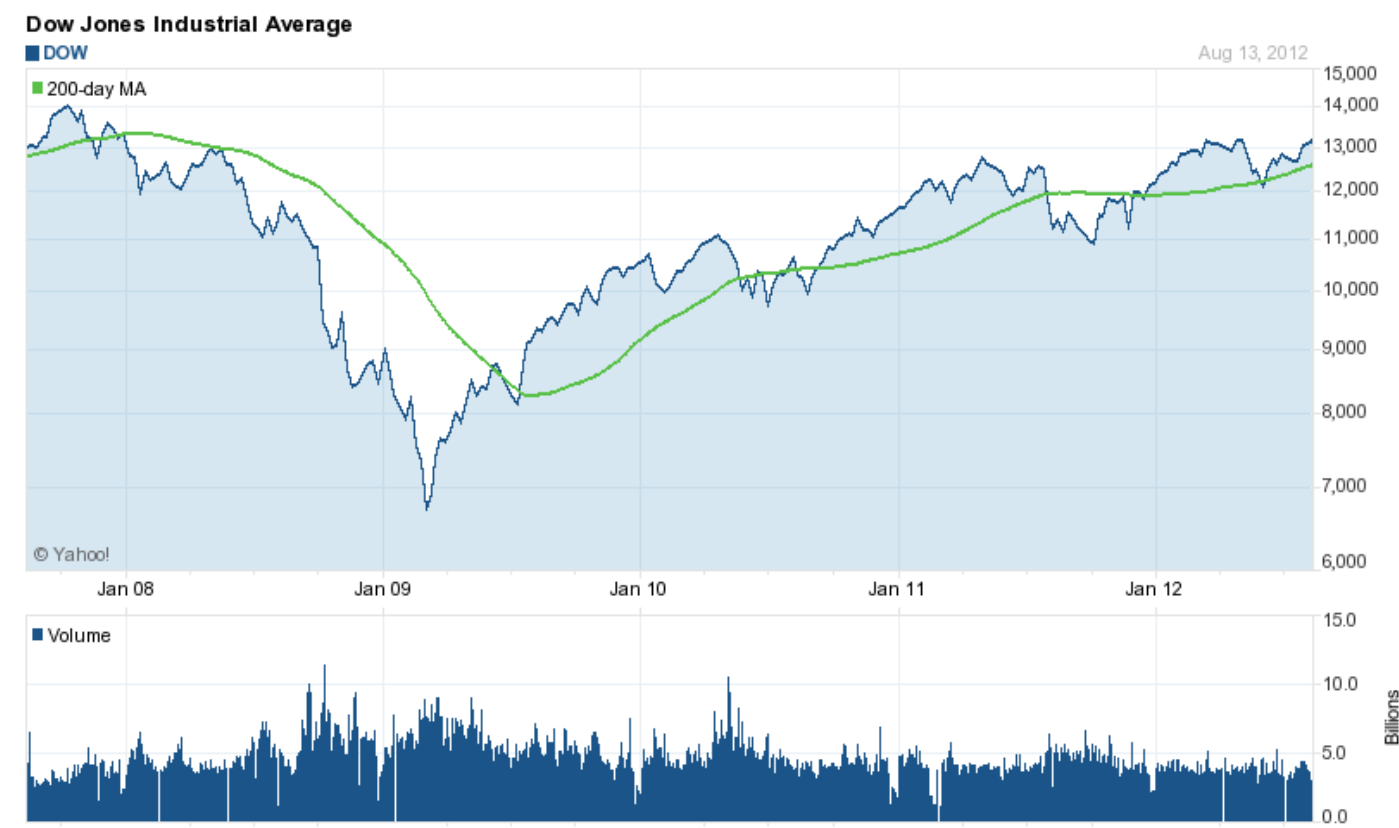

Slika 1 Dow Jones Industrial Averages (www. Yahoofinace.com, 2012.) 


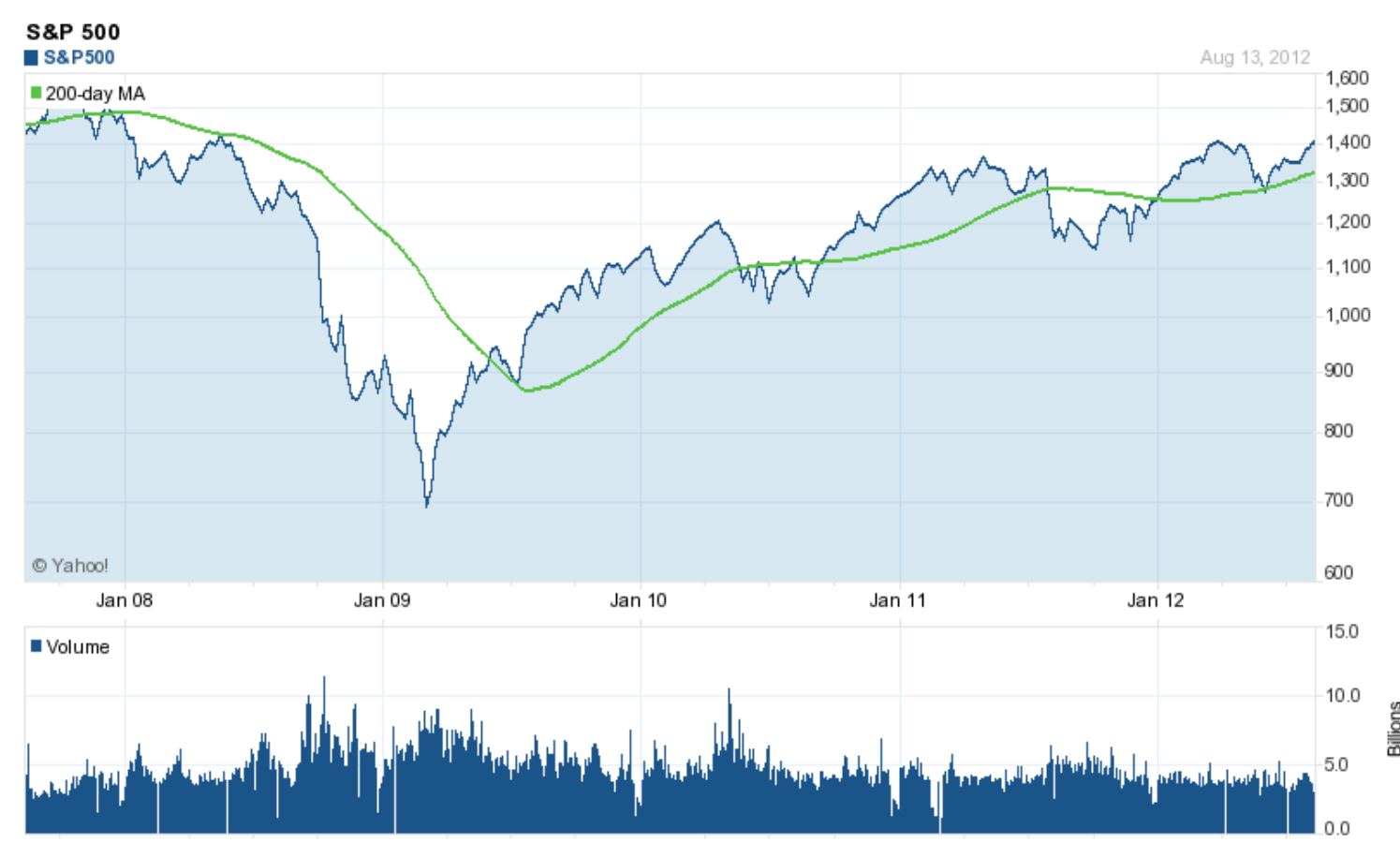

Slika 2 S\&P 500 (www.Yahoofinace.com, 2012.)

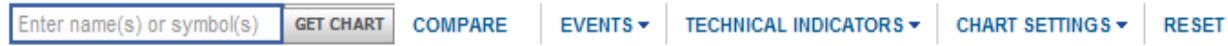

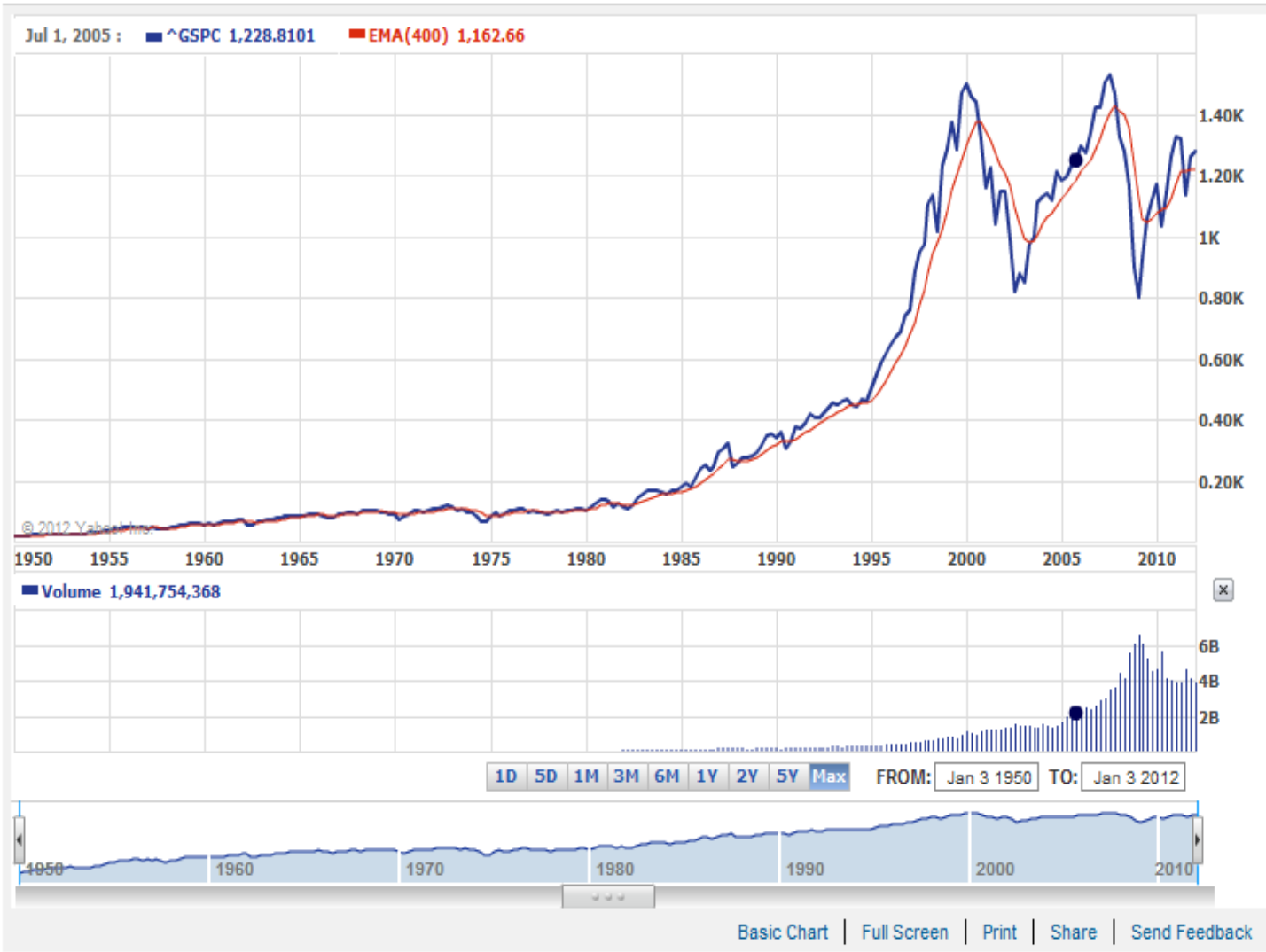

Slika 3 S\&P 500 i MA400 (www. Yahoofinace.com, 2012.) 
Istorijat indeksa S\&P500 pokazuje stalan umeren rast do 90-tih godina dvadesetog veka, da bi od 1995. godine tržište naglo počelo da raste, što je rezultiralo slomom dot-com akcija 2000. godine. Tržište je od 2003. godine nastavilo sa rastom, sve do novog pada 2008.godine i ponovnog rasta od avgusta 2009.godine. Na Slici 3 je korišćen MA 400, radi bolje preglednosti trenda. Zanimljivo je da je $u$ periodu 2000 - 2007. godine došlo do formiranja figure dvostrukog vrha i dna gotovo identičnih vrednosti, a ostaje da se vidi da li će novi trend prestići prethodne vrhove, što bi značilo dalji rast tržišta.

$\mathrm{Ne}$ ignorišući manjkavost tehničke analize, koja ex post ukazuje na promene trenda, ipak i samo približavanje vrednosti indeksa pokretnom proseku, a posebno pad njegove vrednosti ispod pokretnog proseka, ukazuju na promenu trenda, odnosno promenu očekivanja učesnika na tržištu. Drugačije rečeno, tehnički indikatori mogu ukazati na promenu očekivanja učesnika na tržištu, gde preovlađujući pesimizam za rezultat ima pad cena (silazan trend), a optimizam rastući trend.

\section{Pogledi ekonomske nauke na krize kroz istoriju}

Prema klasičnoj ekonomskoj teoriji, čiji je rodonačelnik Adam Smit (1723-1790.god.), „nevidljiva ruka“ tržišta je dovoljna da obezbedi ekonomsku stabilnost i punu uposlenost. Ekonomijom upravljaju racionalni akteri koji sprovode transakcije od kojih imaju ekonomske koristi. Tako, zaposleni koji je voljan da radi po ceni koja je manja od onoga koliko proizvodi, sebi obezbeđuje posao, a kapitalisti koji ga je angažovao omogućava da ostvari profit. Sa druge strane, oni koji koji traže nerazumno visoke nadnice će jedini biti bez posla, pa je takva nezaposlenost voljna. Onog trenutka kada smanje svoje zahteve i oni će se uposliti. Drugim rečima, mehanizam slobodnog tržišta je savršen i stabilan, pa nema potrebe za mešanjem države. Postoji zabluda da je Smit, kao pobornik tržišnog sistema, negirao svaku ulogu države. Naprotiv, Smit je verovao da država može doneti veliku korist ekonomskom životu, posebno kod zaštite ugovora i patenata, državnog obrazovanja za siromašne, infrastrukturnih projekata, uz obezbeđenje mira, niskih poreza i valjanog deljenja pravde. Sve ostalo, po Smitu, donosi prirodan poredak stvari.Verujući u perfektnost funkcionisanja nevidljive ruke, Adam Smit se nije ni upuštao u objašnjenje uspona i padova u ekonomiji.

Po neoklasičnoj ekonomskoj školi, koja se javlja u poslednjoj trećini 19. veka, krize u realnom i finansijskom sektoru, odnosno makroekoenomske neravnoteže nisu ni moguće jer racionalno ponašanje privrednih subjekata i perfektno funkcionisanje robnih i finansijskih tržišta svaku takvu neravnotežu automatski otklanjaju. Neoklasičari veruju da na tržištu novca i kapitala postoji jednaka informisanost svih aktera i nema moralnog hazarda, a da na tržištu radne snage postoji perfektna konkurencija, gde niko ne može da traži i dobije veću platu od ravnotežne (inače ostaje nezaposlen), pri čemu je radna snaga homogena i perfektno mobilna. Proizvođači i potrošači su savršeno racionalni, perfektno upoznati sa svim ograničenjima i strukturom tržišta i u stanju su da pouzdano predvide budućnost. U uslovima perfektne konkurencije, pod kojom se podrazumeva ogroman broj prodavaca i kupaca koji pojedinačno ne mogu da utiču na cene, perfektno korišćenje informacija, koje podrazumeva da svi znaju sve podatke o traženim i ponuđenim proizvodima, uz pretpostavku da svi imaju jednake mogućnosti predviđanja, niko ne može da stekne konkurentsku prednost na osnovu natprosečno dobre anticipacije budućnosti. Pod takvim pretpostavkama garantovana je opšta ravnoteža u privredi koja ne zahteva intervenciju ekonomske politike. Kako je tržište jednako zbiru individualnih učesnika, to u situaciji kada učesnici teže da optimiziraju svoj položaj tržište nekog proizvoda teži ravnoteži. Po neoklasičnoj teoriji su recesije moguće i do njih dolazi zbog sektorskih neravnoteža, ali se u tim slučajevima aktiviraju samokorektivni mehanizmi koji vraćaju tržište u ravnotežu. Drugačije rečeno, problemi na makro nivou ne postoje, jer iako pojedinačno tržište može biti izvan ravnoteže, na agregatnom nivou, ravnoteža je zagarantovana. Drugim rečima, negativna tražnja na bilo kojem pojedinačnom tržištu ima za posledicu višak tražnje $u$ istom iznosu na drugim tržištima, tako da je na agregatnom nivou zbir jednak nuli. Pošto su po neoklasičnoj pretpostavci tržišta savršena, recesije su po definiciji kratkog daha. 
$\mathrm{Na}$ osnovu proučavanja razornih efekata do tada nezabeležene ekonomske krize, nazvane Velikom depresijom, Džon Majnard Kejnz (John Maynard Keynes, 1883-1946.god.) se u svom kapitalnom delu "Opšta teorija zaposlenosti, kamate i novca" (The General Theory of Employment, Interest and Money) suprotstavio neoklasičnom modelu opšte ravnoteže. Kejnz je smatrao da ekonomijom ne upravljaju samo racionalni pojedinci, a celokupnu (agregatnu) potrošnju je podelio na ličnu, investicionu i državnu potrošnju. Po njemu, investicije se preduzimaju na osnovu toga koliki profit očekuju preduzetnici. Pad potražnje na tržištu potrošnih proizvoda vodi padu prodaje, pa samim tim vodi i padu profita, što ima za posledicu i smanjenjenje potražnje za investicionim dobrima. Manje investicija vodi manjoj proizvodnji, manjoj zaposlenosti, stanovništvo postaje siromašnije, što dalje vodi padu u ličnoj potrošnji. Drugim rečima, negativna tražnja na tržištu potrošnih dobara može voditi negativnoj tražnji na tržištu investicionih dobara, što može, u krajnjem ishodu, aktivirati spiralu sa silaznim trendom. Državni troškovi i oporezivanje igraju važnu ulogu preko uticaja na agregatnu tražnju, a promenama visine ovih troškova se mogu neutralisati efekti autonomnih promena investicija na bruto domaći proizvod. Kako je, po Kejnzu, nedovoljna agregatna tražnja u dugom vremenskom periodu osnovni razlog zašto su neregulisane kapitalističke privrede sklone krizama i depresijama, svaki inicijalni stimulans koji potekne od vlade u vidu potrošnje proizvodi multiplikatorski efekat povećanja potrošnje, odnosno povećanja agregatne tražnje. Za razliku od klasičara koji su se prevashodno bili okupirani pitanjima na duge staze, Kejnz je proučavao kratkoročno delovanje ekonomskih faktora, što se može ilustrovati njegovom poznatom izrekom „na dugi rok, svi smo mrtvi“.

Sedamdesetih godina $X X$ veka razvila se novoklasična ekonomska teorija, po kojoj Kejnz u svojim modelima nije dovoljno pažnje posvetio formiranju očekivanja tržišnih učesnika. Novoklasičari Robert Lucas i Thomas Sargent polaze od hipoteze racionalnih očekivanja, po kojoj tržišni učesnici kontinuirano koriste sve raspoložive informacije, odnosno nalaze se na optimalnom putu prilagođavanja. Samim tim, ekonomska politika neće imati efekta ni u kratkom roku na ekonomski sistem jer, na primer, tržišni učesnici znaju da povećanje ponude novca ima za posledicu inflaciju. Tako će, u uslovima povećane ponude novca, oni odmah prilagoditi svoje cene, neće upasti u novčanu iluziju i jedini efekat koji će imati ekonomska politika jeste povećana inflacija. Drugim rečima, prilagođavanje je trenutno, tržište je savršeni samoregulativni mehanizam i svaki pokušaj države da utiče na privredna kretanja će učiniti stvari samo gorim nego što jesu.

Moderna finansijska teorija se bazira na pretpostavci da je tržište savršen mehanizam koji uvek teži ravnotežnom stanju. Ključna pretpostavka, na bazi koje je izveden zaključak moderne finansijske teorije efikasnih tržišta, koju je formulisao ekonomista Eugen Fama sredinom šezdesetih godina XX veka, je da cene finansijskih instrumenata $u$ dugom roku verno oslikavaju fundamentalnu vrednost kapitalnih dobara na koje glase i da "sveznajućim“ slobodnim tržištima nije inherentna nestabilnost. Po teoriji efikasnih tržišta, dugoročno odstupanje cena hartija od vrednosti od fundamentalne vrednosti je moguće u slučaju delovanja nekog egzogenog šoka, najčešće zahvaljujući primeni pogrešno propisanih mera ekonomske politike. Stoga, ukoliko egzogeni remetilački faktori ne dejstvuju, cene finansijskih instrumenata su u dugom roku u skladu sa fundamentalnom vrednošću realne aktive na koju glase, odnosno cene su u ravnoteži. Dugo vladajući Model kapitalne aktive (Capital Asset Princing Model-CAPM), takođe je polazio od racionalnog investitora koji usklađuje prinos i rizik uz čvrsto uverenje da finansijska tržišta perfektno funkcionišu, što znači da se cena finansijske aktive nepogrešivo formira na osnovu svih raspoloživih informacija.

Uvažavajući stav da bi osnovni cilj ekonomske teorije trebalo da bude da što realnije aproksimira realnost, to imlicira neophodnost realnijeg uvažavanja društvenog okruženja, kako bi se izbegla zamka kreiranja apstraktnih, opštih teorijskih postulata koji su na papiru za sve prilike i za sva vremena, a neprimenljivih u praksi. Kako teorijski zakljičci dominantno zavise od pretpostavki modela, to implicira da pogrešne, odnosno nerealne pretpostavke, vode pogrešnim (nerealnim) zaključcima. U svetu u kome dominiraju transnacionalne kompanije, gde su proizvodi heterogeni, konkurencija oligopolska, informacije asimetrične, gde dominira ekonomija obima, ulazak konkurencije u neku granu često težak i skup, tržišta rada visoko specijalizovana i segmentisana, odluke se donose u uslovima visoke neizvesnosti. Shodno tome, može se zaključiti da su pretpostavke 
perfektne konkurencije u savremenim tržišnim uslovima nerealne, odnosno ne postoje, pa stoga nisu primenljivi ni njeni teorijski zaključci.

\section{Uzroci i razmere finansijske krize iz 2008. godine}

Finansijska kriza koja započinje u 2007., a eskalira polovinom 2008.godine je najdublja kriza nakon II Svetskog rata. Primarno nastala u SAD krahom hipotekarnog kreditnog tržišta, kriza se brzo proširila na ceo svet i pored finansijskog, zahvatila i realan sektor. Utvrđivanja uzroka krize je važno radi iznalaženja adekvatnog leka u sadašnjosti i adekvatne preventive ponovne pojave u budućnosti. Po jednom gledištu, uzroci krize se kriju u pogrešnim pretpostavkama akademske ekonomije o racionalnom ponašanju proizvođača $i$ potrošača $i$ perfektnoj konkurenciji, neadekvatnim metodima ocene rizika, odnosno sistemskom riziku koji privredni subjekti ne mogu otkloniti uobičajenim tehnikama na finansijskim tržištima. Finansijska i ekonomska kriza su posledica pogoršanja stanja u realnom sektoru visokorazvijenih zemalja, koje u poslednjoj deceniji beleže usporeniji rast bruto domaćeg proizvoda. Tako je u periodu 20022011.godine prosečna stopa rasta BDP u SAD iznosila samo 1,6\%, u Japanu oko $1 \%$, u evrozoni rast iznosi $1,3 \%$, dok je $u$ isto vreme Kina beležila prosečan rast od skoro $10 \%$. Pad produktivnosti kod visokorazvijenih zemalja je bio evidentiran znatno pre početka krize, kao i pad zaposlenosti i visine nadnica.

Po drugom gledištu, kriza je izazvana neadekvatnom ekonomskom politikom i pohlepom pojedinih grupa, posebno finansijskih institucija i kompanija kroz njihovo nastojanje da zarade ogromne provizije. U nastojanju da se ostvare visoki profiti ulazilo se u sve rizičnija ulaganja. Međutim, pokušaj opravdanja krize pohlepom pojedinaca je dosta neubedljivo, posebno što pohlepa i sebičnost od davnina spadaju u karakteristike ljudskog roda. U neumoljivoj trci za profitom kompanije su gledale samo sopstvene interese, a međusobna konkurencija finansijskih organizacija in je praktično prisiljavala na prekomerno ulaženje $u$ rizik $i$ zaduživanje. To je i bio razlog „pucanja balona“ nastalog prekomernim i nepokrivenim hipotekarnim stambenim kreditima u SAD. Suočeni sa stagnacijom privrednog rasta i odsustvom dovoljno profitabilnih inostranih investicionih alternativa u SAD se pribeglo posticanju stambene izgradnje, koja je motor razvoja mnogih sa njom povezanih privrednih grana. Da bi se podstakla tražnja za stanovima kroz sniženje kreditnih standarda i povoljnim kreditnim uslovima u kupovunu stanova i kuća su se upustili i oni koji do juče o tome nisu mogli ni da sanjaju. Niske kamatne stope, koje su u početnim godinama otplate bile fiksne i niže od eskontne stope, uz stalan rast cena nekretnina se činilo kao idealan i bezrizičan posao. Ekspanzijom jeftinih kredita bez odgovarajućeg kolaterala, koji su prestali da budu tako jeftini kada je nastupio period varijabilnih, odnosno kamatnih stopa koje su se usklađivale prema tržišnim kamatnim stopama i konstantan rast cena nekretnina su naduvavale balon koji je jednom morao da pukne. Za krizu su odgovorne i rejting agencije (Standard \& Poor's, Moody i Fitch) koje su hipotekarnim oveznicama (mortgage-becked securities) davale prevelik rejting od AAA, što znači da su te hartije ocenjene kao manje rizične od samih hipoteka. Nepoverenje na finansijskim tržištima, inicirano padom cena nekretnina, proizvelo je nelikvidnost, skok kamatnih stopa, izazvalo oštar pad mnogih berzanskih indeksa. S obzirom na isprepletanost tržišta, kriza se brzo prenela iz SAD na ostatak sveta, donoseći veliki pad proizvodnje u mnogim zemljama, pad stambene izgradnje i sa njom povezanih industrija, pad zaposlenosti, odliv inostranog kapitala, stagnaciju privrednog rasta i pad društvenog proizvoda u mnogim zemljama, pad poverenja $i$ cena na finansijskim tržištima. U takvim okolnostima mnogi su ušli u zonu gubitka, što je uticalo na smanjenje potrošnje i investicija uz pad zaposlenosti, što je dovelo do depresije. Sa druge strane rasli su javna potrošnja i budžetski deficiti. Dubinu i razmere svetske finansijske krize ilustruje podatak da se nakon trideset godina rasta vrednosti globalne finansijske aktive, koja obuhvata tržišnu kapitalizaciju akcija i emitovane obveznice i zajmove u 79 zemalja sveta, u 2008. godini taj trend prekida, a vrednost finansijske aktive opada sa 202 na 175 triliona USD. U periodu 1990-2009.godine najveći rast od skoro $13 \%$ godišnje su imale tzv. sekjutirizovane hartije od vrednosti, (posebno sekjuritizovani hipotekatni stambeni krediti). Globalni dugovi su se više nego udvostručili u zadnjih 10 godina, odnosno porasli su sa 78 triliona USD u 2000. na 158 triliona USD 2010. godine. Dugovi su rasli brže od rasta BDP, tako da je racio globalni dug/BDP, porastao na $266 \%$ u 2010.godini. Jedna 
od najvećih konsekvenci svetske finansijske krize je bio pad prekograničnog protoka kapitala (crossborder capital flows), u koje se uključuju strane direktne investicije (foreign direct investment-FDI), kupovine i prodaje stranih vlasničkih i dugovnih hartija od vrednosti i prekogranične pozajmice $i$ depoziti, od oko $85 \%$ (sa 10,9 triliona USD u 2007 , na 1,9 triliona USD u 2008. godini i samo 1,6 triliona USD u 2009. godini), što je negativno uticalo na ponudu kapitala. Posebno je velik pad na tržištima kapitala, gde je tržišna kapitalizacija obuhvaćenih 79 zemalja pala sa 65 triliona 2007.godine na 34 triliona USD u 2008. godini, ili skoro dva puta. Poslednje dve godine rast je ponovo nastavljen. Rast od 14 triliona USD tržišne kapitalizacije u 2009.godini u odnosu na prethodnu godinu i rast tržišne kapitalizacije od 6 triliona USD u 2010.godini su rezultat očekivanog rasta dobiti i novih emisija, prevashodno kompanija na rastućim tržištima. Međutim, u 2011. godini tržišna kapitalizacija je pala za preko $8 \%$, na 47 triliona USD.

Obim finansijskih transakcija je danas znatno iznad vrednosti produktivnih investicija. Suprotno vladajućoj modernoj finansijskoj teoriji, po kojoj je osnovna funkcija finansijskih tržišta efikasna diversifikacija rizika i efikasna alokacija resursa, finansijska tržišta su postala svrha sebi samima. Prvih osam decenija dvadesetog veka finansijska aktiva je rasla istim tempom kao i globalni BDP, nakon čega količnik vrednosti globalne finansijske aktive i godišnjeg svetskog bruto domaćeg proizvoda konstantno raste, tako da je porastao na gotovo 442\% 2007.godine. Drugim rečima, obimi transakcija na globalnim finansijskim tržištima daleko prevazilaze vrednost svetske trgovine, što navodi na zaključak da je realni sektor postao „privezak“ finansijskom sektoru. Separacija između realnog i finansijskog sektora se u literaturi naziva finansijalizacija (financialization). Posledice finansijalizacije su sve izraženiji transfer dohotka iz realnog u finansijski sektor, sve veća dohodovna nejednakost i sve izraženiji uticaj finansijskih motiva na upravljanje kompanijama. Kada se cena određene finansijske aktive izvodi iz odnosa sa cenama ostale finansijske aktive bez ikakve veze sa stanjem i kretanjima u realnom delu privrede, formiraju se „baloni“ na osnovu nerealnih očekivanja, čije pucanje označava početak finansijske krize.

\section{Moguća rešenja za prevazilaženje svetske finansijske krize}

Po nastupanju nesolventnosti velikih američkih banaka i drugih finansijskih institucija nizom mera je pokušana stabilizacija finansijskih tržišta. Državna intervencija obuhvatala je davanje garancija za međubankarske transakcije i kredite velikim kompanijama, povećanje iznosa garantovanog depozita, emitovanje državnih obveznica. Rekapitalizacija banaka i fiskalna stimulacija tražnje u realnom sektoru je dovela do rasta budžetskog deficita u odnosu na bruto domaći proizvod SAD. Zahvaljujući činjenici da je američki dolar i dalje glavna svetska valuta u međunarodnom platnom prometu, da je glavna moneta deviznih rezervi mnogih zemalja, kao i činjenici da se preko $70 \%$ emitovanih novčanica od 100 dolara nikada ne vrati u SAD, moguće je finansiranje ogromnog trgovinskog deficita štampanjem dolara bez rizika od inflacije. Tako je dolar na neki način postao najvažniji američki izvozni proizvod, a SAD zahvaljujući ogromnom tržištu najveći trgovinski partner mnogih zemalja. Drugim rečima, SAD sebi mogu da dozvole velike deficite trgovinskog i platnog bilansa jer druge zemlje rado idu sa njima u suficit povećavajući time svoje devizne rezerve.

Može se reći, da su nakon Velike depresije, stimulativne mere fiskalne politike (javna potrošnja, porezi i upravljanje dugovima), koje je tada zagovarao John Maynard Keynes i u ovoj krizi ponovo dobile na značaju. Fiskalna politika mnogih zemalja u ovoj krizi je usmerena na stimulisanje privrednih aktivnosti povećanjem tražnje, zaposlenosti $\mathrm{i}$ investicija $\mathrm{u}$ infrastrukturne objekte (putevi, energetika, gasovodi i sl.), pospešivanja razvoja malih i srednjih preduzeća, podsticanjem potrošnje putem smanjenja poreza i doprinosa na lična primanja, subvencionisanja potrošačkih kredita građana i kredita privredi, davanja socijalne pomoći nezaposlenima i socijalno ugroženim kategorijama. U nekim zemljama važan deo planova oporavka su predstavljala izdvajanja značajnih sredstava za ustraživanje i razvoj, tehnološke projekte i obrazovanje.

Kriza je ukazala na potrebu konstituisanja novih globalnih reprezentativnih tela na nivou šefova država i vlada, koje bi koordinirale funkcionisanje svetskog ekonomskog sistema (usmeravale ekonomski i socijalni razvoj, konkurentnost, regulativu finansijskih tržišta, ekologiju, globalno 
zagrevanje i sl.). Takođe se postavilo i pitanje nephodnosti reformisanja institucija, kao što su Svetska banka i Međunarodni monetarni fond. Uvidela se neophodnost usaglašavanja regulatornih sistema da bi se obezbedila pouzdanost finansijskih proizvoda, naročito finansijskih derivata. Posebno je važna regulacija finansijskih tržišta, kojom je neophodno zaštiti adekvatno ulagače. Pri tome je neophodno voditi računa da se ne uguši „kreativnost“ na tim tržištima. Potpunija i efikasnija regulativa trebalo bi da obuhvati i agencije za kreditni rejting, pri čemu se čuju i glasovi koji ukazuju na neophodnost formiranja respektabilne institucije tog tipa i u evro zoni.

U cilju obezbeđenja boljeg sistema zaštite od rizika nego što su devizne rezerve, predlaže se novi globalni rezervni sistem zasnovan na značajno povećanoj ulozi specijalnih prava vučenja. Posebno se apostrofira uloga centralnih banaka $u$ obezbeđenju stabilnosti cena, očuvanju finansijske stabilnosti tokova kapitala, adekvatnosti kurseva nacionalnih valuta uz ostvarenje dugoročno održivog privrednog rasta. Da bi se smanjio obim spornih pitanja u međunarodnom finansijskom sistemu, potrebno je uspostaviti jedan opšte prihvatljivi mehanizam za restrukturiranje duga država i harmonizovati nacionalne propise 0 rešavanju sporova povodom prekograničnih investicija.

Kao pet neophodnih mera da bi evro zona preživela trenutnu krizu se ističu: (1) donošenje programa za smanjenje preteranih državnih dugova, (2) agresivnije planiranje smanjenja budžetskih deficita u bliskoj budućnosti, 3) podrška monetarnim politikama od strane Evropske centralne banke, (4) uvođenje mehanizama koji postiču dugoročnu fiskalnu održivost, i (5) institucionalne promene koje smanjuje prostor za prekomerno zaduživanje i izazivanje nestabilnosti u finansijskom sektoru.

\section{ZAKLJUČAK}

Globalna finansijska i ekonomska kriza je donela puno nevolja: veliki pad proizvodnje u mnogim zemljama, a posebno pad stambene izgradnje i sa njom povezanim industrijama, pad zaposlenosti, odliv inostranog kapitala, pad poverenja na finansijskim tržištima i posledično pad cena, stagnaciju rasta i pad društvenog proizvoda $u$ mnogim zemljama. Kako su finansijska i ekonomska kriza zahvatile veliki broj zemalja, to se u otklonjanju njenih posledica moraju tražiti globalna rešenja. $U$ uslovima visokog stepena integrisanosti tokova u svetskoj privredi neophodno je formirati kompetentne institucije i utvrditi metode i standarde za sprečavanje i rešavanje posledica finansijskih i ekonomskih kriza.

Mnoge zemlje su odmah po izbijanju krize promtno reagovale relaksiranjem monetarne politike upumpavanjem velike količine novca uz veoma niske kamate $u$ nesolventne banke $i$ druge finansijske organizacije. Fiskalnom politikom su podsticane privredne aktivnosti, ali za dugoročniji oporavak je neophodna sveokupna stabilizacija finansijskog sistema, stvaranje uslova za ubrzaniji privredni rast i njegovo podsticanja investiranjem $u$ infrastrukturu i ljudske resurse, kao ključnih faktora dugoročnog razvoja i smanjenja nezaposlenosti. Otklanjanje makroekonomskih neravnoteža je od esencijalnog značaja, kako bi se umanjila mogućnost ponovnog izbijanja krize u budućem periodu.

\section{Citirani radovi}

Akerlof, Dž., Šiler, R. (2010). Životni duh. Beograd: Službeni glasnik.

Anon. $(2011,08)$. Updating global capital markets and flows 2011. Retrieved from McKinsey Quarterly: http://www.mckinseyquarterly.com/Updating_global_capital_markets_and_flows_2011_2842

Boone, P., Johnson, S. (2011 04 10). The Future of Banking: Is More Regulation Needed?. Peterson Institute for International Economics.

Dees, S., \& Saint-Guilhem, A. $(2009,03)$. The role oh the United States in the global economy and its evolution over time. Working Paper Series(1034), 1-44. Retrieved from European Central Bank: http://www.ecb.europa.eu/pub/pdf/scpwps/ecbwp1034.pdf

Kovač, O. (2009, 10 30). Uzroci i mogući koncepti rešavanja svetske finansijske krize. Retrieved from Nova srpska politička misao: http://www.nspm.rs/ekonomska-politika/uzroci-i-moguci-koncepti-resavanja-svetske-finansijske-krize.html Krugman, P. (2007). Afterthe Money's Gone. New York: The New York Times, Editorial, 14, December, 2007. 
Brzaković T. Svetska finansijska kriza i putevi izlaska FBIM Transactions Vol. 1 No. 1 pp. 47 - 55

Krugman, P. (2009). How Did Economists Get it so Wrong?. New York: The New York Times, September 6, 2009. OECD. (2011). OECD Economic Outlook. Vol. 2010/2. OECD Publishing. doi: 10.1787/eco_outlook-v2010-sup2-en. Radonjić, O. (2009, 02 20). Keynesova teorija konvencionalnog odlučivanja na finansijskim tržištima. doi:10.2298/SOC0904337R

Reinhart, C. M., \& Rogoff, K. S. $(2008,05)$. Is the 2007 U.S. Sub-Prime Financial Crisis So Different? An International Historical Comparison. American Economic Review, 98(2), 339-44. Retrieved from the National Bureau of Economic Research.

Roxburgh, C., Lund, S., \& Piotrowski, J. (2011, 08). Mapping global capital markets 2011. Retrieved from McKinsey Global Institute: http://www.mckinsey.com/insights/mgi/research/financial_markets/mapping_global_capital_markets_2011

Strauss-Kahn, D. (2008 02). Lessons from the Financial Market Crisis: Priorities forthe World and forthe IMF. New Delhi: ICRIER.

World Bank. (2008). Global Economic Prospects 2008: Technology Diffusion in the Developing World. Global Economic Prospects, 1-16.

Datum prve prijave:

Datum prihvatanja članka:
02.10.2012.

16.11.2012.

\section{Kako citirati ovaj rad?}

Style - APA Sixth Edition:

Brzaković, T. (2013, 01 15). Menadžment u kriznim situacijama - uzroci i razmere svetske finansijske krize i putevi izlaska. (Z. Čekerevac, Ed.) FBIM Transactions, 1(1), 47-55. Retrieved from www.meste.org/fbim/FBIM 1 2013/ 05.pdf. doi: 10.12709/fbim.01.01.01.05

\section{Style - Chicago Fifteenth Edition:}

Brzaković, Tomislav. "Menadžment u kriznim situacijama - uzroci i razmere svetske finansijske krize i putevi izlaska." Edited by Zoran Čekerevac. FBIM Transactions (MESTE NVO) 1, no. 1 (01 2013): 47-55.

Style-GOST Name Sort:

Brzaković Tomislav Menadžment u kriznim situacijama - uzroci i razmere svetske finansijske krize i putevi izlaska [Journal] = Svetska finansijska kriza i putevi izlaska // FBIM Transactions / ed. Čekerevac Zoran. Beograd : MESTE NVO, 01 15, 2013. - 1 : Vol. 1. - pp. 47-55.

\section{Style - Harvard Anglia:}

Brzaković, T., 2013. Menadžment u kriznim situacijama - uzroci i razmere svetske finansijske krize i putevi izlaska. FBIM Transactions, 15 01, 1(1), pp. 47-55.

Style - ISO 690 Numerical Reference:

Menadžment u kriznim situacijama - uzroci i razmere svetske finansijske krize i putevi izlaska. Brzaković, Tomislav. [ed.] Zoran Čekerevac. 1, Beograd : MESTE NVO, 01 15, 2013, FBIM Transactions, Vol. 1, pp. 47-55. 